\title{
Guillain-Barré Syndrome During Ongoing Zika Virus Transmission - Puerto Rico, January 1-July 31, 2016
}

\begin{abstract}
Emilio Dirlikov, PhD ${ }^{1,2}$; Chelsea G. Major, MPH ${ }^{3,4}$; Marrielle Mayshack ${ }^{1,4}$; Nicole Medina, MPH${ }^{3}$; Desiree Matos ${ }^{3}$; Kyle R. Ryff, MPH ${ }^{1}$; Jomil Torres-Aponte, $\mathrm{MS}^{1}$; Rebecca Alkis ${ }^{5}$; Jorge Munoz-Jordan, $\mathrm{PhD}^{3}$; Candimar Colon-Sanchez, MS ${ }^{3}$; Jorge L. Salinas, MD²; Daniel M. Pastula, MD ${ }^{3,6}$; Myriam Garcia, MT ${ }^{7,8}$; Marangely Olivero Segarra, $\mathrm{MS}^{7,8}$; Graciela Malave, MT ${ }^{7,8}$; Dana L. Thomas, MD ; Gloria M. Rodríguez-Vega, MD ${ }^{10}$; Carlos A. Luciano, $\mathrm{MD}^{11}$; James Sejvar, $\mathrm{MD}^{12}$; Tyler M. Sharp, $\mathrm{PhD}^{3}$; Brenda Rivera-Garcia, DVM ${ }^{1}$
\end{abstract}

On August 26, 2016, this report was posted as an MMWR Early Release on the MMWR website (http://www.cdc.gov/mmwr). Guillain-Barré syndrome (GBS) is a postinfectious autoimmune disorder characterized by bilateral flaccid limb weakness attributable to peripheral nerve damage (1). Increased GBS incidence has been reported in countries with local transmission of Zika virus, a flavivirus transmitted primarily by certain Aedes species mosquitoes (2). In Puerto Rico, three arthropod-borne viruses (arboviruses) are currently circulating: Zika, dengue, and chikungunya. The first locally acquired Zika virus infection in Puerto Rico was reported in December 2015 (3). In February 2016, the Puerto Rico Department of Health $(\mathrm{PRDH})$, with assistance from CDC, implemented the GBS Passive Surveillance System (GBPSS) to identify new cases of suspected GBS (4). Fifty-six suspected cases of GBS with onset of neurologic signs during January 1-July 31, 2016, were identified. Thirty-four (61\%) patients had evidence of Zika virus or flavivirus infection; the median age of these patients was 55 years (range $=21-88$ years), and $20(59 \%)$ patients were female. These 34 patients were residents of seven of eight PRDH public health regions. All 34 patients were hospitalized and treated with intravenous immunoglobulin G (IVIg), the standard treatment for GBS; 21 (62\%) required intensive care unit admission, including 12 (35\%) who required endotracheal intubation and mechanical ventilation. One patient died of septic shock after treatment for GBS. Additionally, 26 cases of neurologic conditions other than GBS were reported through GBPSS, including seven (27\%) in patients with evidence of Zika virus or flavivirus infection. Residents of and travelers to Puerto Rico and countries with active Zika virus transmission should follow recommendations for prevention of Zika virus infections.* Persons with signs or symptoms consistent with GBS should promptly seek medical attention. Health care providers in areas with ongoing local transmission seeing patients with neurologic illnesses should consider GBS and report suspected cases to public health authorities.

\footnotetext{
*http://www.cdc.gov/zika/prevention/.
}

\section{Epidemiologic Surveillance for GBS}

In February 2016, as part of the ongoing response to local Zika virus transmission (3-5), PRDH implemented GBPSS with CDC assistance. Health care providers throughout the island are requested to report all patients with suspected GBS to $\mathrm{PRDH}$ by submitting a case report form ${ }^{\dagger}$ along with patient specimens (serum, urine, cerebrospinal fluid [CSF], and saliva). Reporting of patients with other neurologic disorders and a suspected antecedent arboviral infection is also encouraged. All submitted specimens are tested at CDC Dengue Branch (San Juan, Puerto Rico) or PRDH Biological and Chemical Emergencies Laboratory using a Trioplex reverse transcriptionpolymerase chain reaction (RT-PCR) assay to detect nucleic acid from Zika, dengue, and chikungunya viruses. ${ }^{\$}$ Serum and CSF specimens are also tested by immunoglobulin $M$ (IgM) enzyme-linked immunosorbent assay (ELISA) for all three viruses. Persons with Zika virus nucleic acid detected by RT-PCR in any specimen are considered to have confirmed Zika virus infection. Persons with negative results for Zika virus by RT-PCR in all specimens tested are considered to have presumptive recent infection with a single arbovirus when results are positive for that virus by IgM ELISA, and presumptive flavivirus infection if they test positive for both Zika virus and dengue virus by IgM ELISA. Neurologic diagnosis for GBS cases with evidence of arboviral infection was confirmed by chart review using the Brighton Collaboration criteria, a set of standardized diagnostic criteria based on clinical presentation, CSF laboratory results, and electrophysiologic findings (6). Chart reviews are performed after hospital discharge, $>28$ days after onset of neurologic signs for persons who remain hospitalized, or death.

Fifty-six suspected cases of GBS with onset of neurologic signs during January 1-July 31, 2016, were identified, including one case identified before implementation of GBPSS and

\footnotetext{
$\dagger$ The GBS case report form is available in both Spanish (http://www.salud.gov. pr/Sobre-tu-Salud/Documents/Español.pdf) and English (http://www.salud. gov.pr/Sobre-tu-Salud/Documents/ingl\%c3\%a9s.pdf).

$\$$ http://www.fda.gov/\%20EmergencyPreparedness/Counterterrorism/ MedicalCountermeasures/MCMIssues/ucm485199.htm.
} 
two cases identified during a mid-year assessment of the surveillance system. Among identified suspected cases of GBS, 20 patients $(37 \%)$ had no evidence of Zika virus infection, two (4\%) patients had pending laboratory test results, and 34 (61\%) patients had any evidence of Zika virus or flavivirus infection. Among these 34 patients, 10 (18\%) had confirmed Zika virus infection, 16 (29\%) had presumptive Zika virus infection, and eight (14\%) had presumptive flavivirus infection. Additionally, one (2\%) patient had equivocal results for both Zika and dengue virus by IgM ELISA, and three (5\%) had equivocal results for chikungunya virus by IgM ELISA.

During January-July 2016, the median monthly case count of persons with suspected GBS and no evidence of Zika virus infection or pending laboratory results, by month of onset of neurologic signs, was three (range $=1-5$ ). Overall, the number of persons with suspected GBS and evidence of Zika virus or flavivirus infection was 2.5 times greater than the number of persons with suspected GBS and no evidence of Zika virus infection, with an increasing number of cases occurring each month beginning in April (Figure 1). The 34 patients with suspected GBS and evidence of Zika virus or flavivirus infection were residents of seven of eight PRDH health regions (Figure 2); the median age of these patients was 55 years (range $=21-88$ years), and 20 (59\%) of the 34 patients were female.

Charts have been reviewed for 32 of these 34 patients; GBS was confirmed for all 32 . Acute illness during the preceding 2 months was recorded in the medical charts of 30 (94\%) patients (Table). The most frequently reported symptoms associated with the reported antecedent acute illness were rash $(\mathrm{n}=18,53 \%)$, fever ( $n=12,35 \%)$, and diarrhea $(n=7,21 \%)$. Median interval from antecedent acute illness to onset of neurologic signs was 5 days (range $=0-17$ days). All 34 patients were hospitalized after onset of neurologic signs, and among patients who were discharged $(\mathrm{n}=28)$ or had died $(\mathrm{n}=1)$ as of August 18, median duration of hospitalization was 12 days (range $=6-47$ days). Among the 32 patients with completed chart reviews, the most common recorded clinical neurologic signs and symptoms were hyporeflexia or areflexia $(\mathrm{n}=31,97 \%)$, leg weakness $(\mathrm{n}=31,97 \%)$, leg paresthesia $(n=24,75 \%)$, arm weakness $(n=24,75 \%)$, facial weakness $(n=20,63 \%)$, arm numbness $(n=19,59 \%)$, and dysphagia $(\mathrm{n}=19,59 \%)$. All 25 patients who underwent lumbar punctures had cytoalbuminologic dissociation (increased CSF protein concentration and total CSF white blood cell count $<50$ cells $/ \mu \mathrm{l})$, which is frequently observed in patients with GBS. Five patients had electrophysiologic testing, which indicated the acute inflammatory demyelinating polyneuropathy subtype of GBS in all five. All 34 patients were treated with IVIg. As of August 18, 21 (62\%) of 34 patients had been admitted to intensive care units, and $12(35 \%)$ required mechanical ventilation.
FIGURE 1. Reported cases of confirmed and suspected Guillain-Barré syndrome $(n=56)$, by Zika virus laboratory result and month of onset of neurologic signs - Puerto Rico, January 1-July 31, 2016

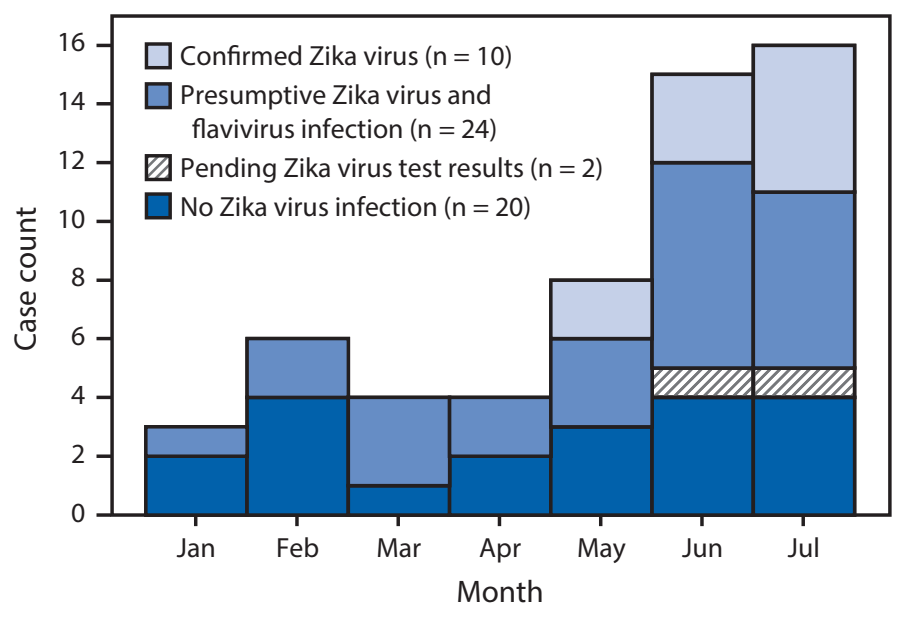

As of August 18, five (15\%) patients remained hospitalized, 15 (44\%) were discharged home, and $13(38 \%)$ were transferred to a rehabilitation or skilled nursing facility. One patient $(3 \%)$ with presumptive flavivirus infection died of septic shock, despite treatment with broad-spectrum antibiotics.

Additionally, 26 cases of neurologic disorders other than GBS were reported to PRDH via GBPSS; seven (27\%) patients had evidence of recent Zika virus or flavivirus infection. The neurologic disorders among these seven patients include three cases of encephalitis (one patient had confirmed Zika virus infection, one had presumptive Zika virus infection, and one had presumptive flavivirus infection); two cases of myelitis, both in patients with confirmed Zika virus infection; one case of acute neurologic deficit, in a patient with confirmed Zika virus infection; and one case of postinfectious papilledema, in a patient with presumptive Zika virus infection.

\section{Surveillance System Assessment}

During July 2016, the surveillance system's completeness in ascertaining suspected cases of GBS was assessed. Thirtytwo $(46 \%)$ of 70 total hospitals on the island were contacted. Hospital staff members from medical records or infection control departments were asked to provide a list of patients who had been hospitalized during January-June 2016, and who had an International Classification of Disease, 10th revision code for GBS (G61.0) in their medical record. Unreported cases of possible GBS were defined as patients who were hospitalized after GBPSS was initiated in mid-February, had hospital stays $>3$ days, and were not reported to GBPSS. Patients with an alternative final diagnosis were excluded. Twenty-six (81\%) of the 32 contacted hospitals responded, including 13 of the 16 hospitals that reported at least one suspected case of GBS and 
FIGURE 2. Reported cases of confirmed and suspected Guillain-Barré syndrome in persons with evidence of Zika virus or flavivirus infection, by public health region of residence — Puerto Rico, January 1-July 31, $2016(\mathrm{~N}=34)$

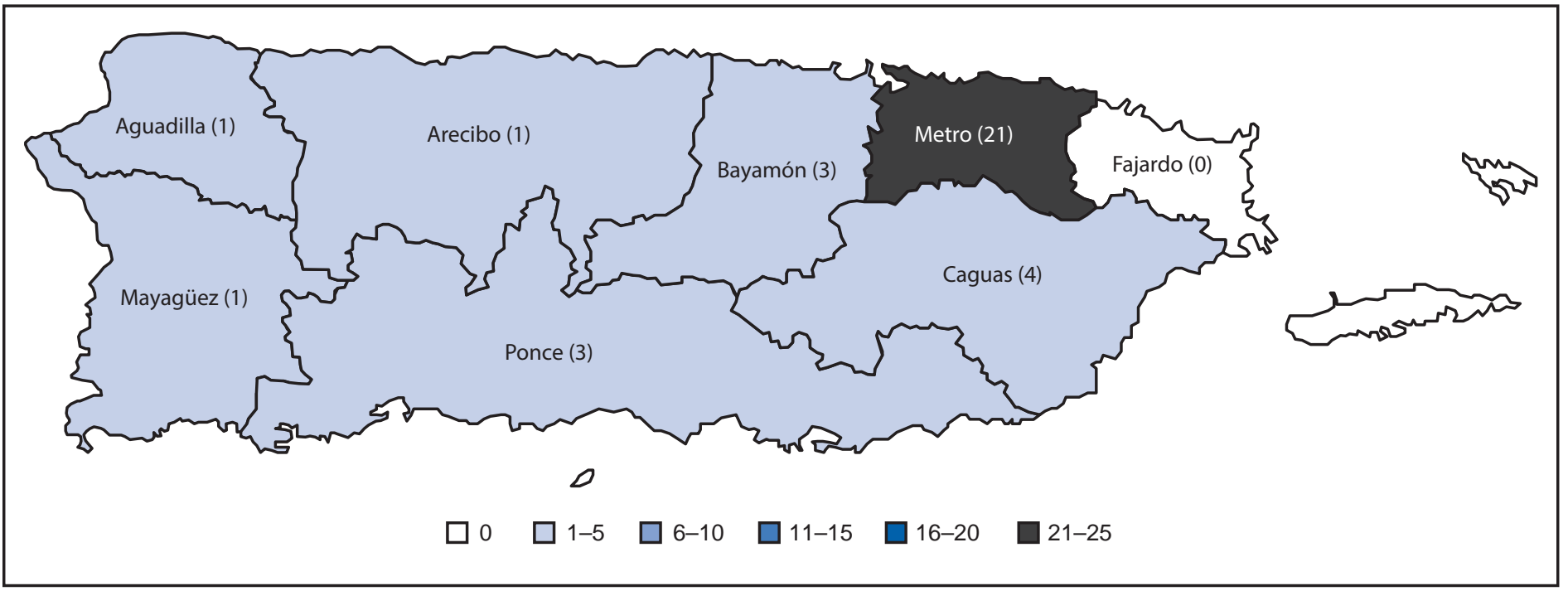

13 hospitals from a purposive sample of 16 hospitals selected randomly among the remaining hospitals on the island after stratifying by hospital size and region.

Two cases of possible GBS that had not been reported directly to GBPSS were identified. Both had specimens submitted to PRDH's Passive Arboviral Diseases Surveillance System shortly before onset of their neurologic illness, which confirmed Zika virus infection. The patients were hospitalized for GBS in May and June respectively, and GBS diagnosis was confirmed by chart review.

\section{Discussion}

Because of the increased incidence of GBS reported in countries affected by Zika virus (7), PRDH implemented GBPSS soon after reporting the first case of Zika virus disease (4). Timely reporting has allowed for identification of ten cases of GBS with Zika virus infection confirmed by RT-PCR. Before this report, only individual cases of confirmed Zika virus infection in patients with GBS have been described (8). Cases of GBS with evidence of flavivirus infection are expected to be attributable to Zika virus, the predominant flavivirus currently circulating in Puerto Rico; during November 1, 2015-July 7, 2016, PRDH identified 5,582 confirmed and presumptive Zika virus cases compared with only 136 cases of dengue virus infections (5). Although fatalities among GBS patients are rare (1), the potential severity and burden of GBS on the health care system are highlighted by the death described here and

\footnotetext{
9 PRDH and CDC Dengue Branch incorporated Zika virus case reporting and diagnostic testing into existing dengue and chikungunya virus surveillance systems and developed a laboratory-based Passive Arboviral Diseases Surveillance System.
}

by the large proportion of patients that required intensive care services, including mechanical ventilation.

Consistent with the global epidemiology of GBS, the median age of patients with suspected GBS and evidence of Zika virus or flavivirus infection was $>50$ years (9). Although GBS generally occurs somewhat more frequently in men than in women (9), the majority of patients described in this report were females. Analyses to explore the unexpected distribution of cases by sex are planned, including an apparent predominance of women in Puerto Rico with Zika virus infections. Although provider outreach activities and GBS case clustering might partially explain increased monthly case counts during April-July, an increased number of cases is consistent with ongoing Zika virus transmission. In French Polynesia, where a Zika virus disease outbreak occurred during 2013-2014, an increase in the number of GBS patients was reported ( 7 ). In contrast to French Polynesia, where electrophysiologic studies (when performed) identified the acute motor axonal neuropathy subtype of GBS (7), in Puerto Rico, the acute inflammatory demyelinating polyneuropathy subtype of GBS was identified in all five GBS cases with evidence of Zika virus or flavivirus infection who had electrophysiologic studies performed. Consistent with other reports that have found a range of neurologic conditions potentially associated with Zika virus infection (10), $27 \%$ of the 26 patients with neurologic conditions other than GBS identified through the GBPSS had evidence of Zika virus or flavivirus infection.

Residents of and travelers to Puerto Rico and countries with ongoing Zika virus transmission should follow recommendations for prevention of Zika virus infections. Given 
TABLE. Characteristics, interpretation of laboratory results, confirmation of neurologic diagnosis, and course of illness in patients with Guillain-Barré syndrome (GBS)* and evidence of Zika virus or flavivirus infection ( $N=34)$ - Puerto Rico, January 1-July 31, 2016

\begin{tabular}{|c|c|}
\hline Characteristic & Median (range) \\
\hline Age (yrs) & $55(21-88)$ \\
\hline $\begin{array}{l}\text { Sex } \\
\text { Female }\end{array}$ & $\begin{array}{c}\text { No. (\%) of patients } \\
20(59)\end{array}$ \\
\hline $\begin{array}{l}\text { Interpretation of laboratory results } \\
\text { Confirmed Zika virus infection } \\
\text { Presumptive Zika virus infection } \\
\text { Presumptive flavivirus infection }\end{array}$ & $\begin{array}{r}10(29) \\
16(47) \\
8(24)\end{array}$ \\
\hline $\begin{array}{l}\text { Confirmation of neurologic diagnosis via chart review } \\
\text { Patient charts reviewed } \\
\text { Patients with confirmed GBS diagnosis } \\
\text { Patients pending chart review }\end{array}$ & $\begin{array}{r}32(94) \\
32(94) \\
2(6)\end{array}$ \\
\hline Course of illness & \\
\hline $\begin{array}{l}\text { Duration (days) }\left(\mathrm{N}=32^{*}\right) \\
\text { Antecedent acute illness to neurologic symptom onset } \\
\text { Hospitalization }{ }^{\dagger}\end{array}$ & $\begin{array}{c}\text { Median (range) } \\
5(0-17) \\
12(6-47)\end{array}$ \\
\hline $\begin{array}{l}\text { Antecedent illness }\left(\mathrm{N}=32^{*}\right) \\
\text { Acute antecedent illness } \\
\text { Rash } \\
\text { Fever } \\
\text { Diarrhea }\end{array}$ & $\begin{array}{l}\text { No. (\%) of patients } \\
30(94) \\
18(56) \\
12(38) \\
7(22)\end{array}$ \\
\hline $\begin{array}{l}\text { Signs and symptoms of neurologic illness }\left(\mathrm{N}=32^{*}\right) \\
\text { Hyporeflexia or areflexia } \\
\text { Leg weakness } \\
\text { Leg paresthesia } \\
\text { Arm weakness } \\
\text { Face weakness } \\
\text { Arm paresthesia } \\
\text { Dysphagia } \\
\text { Cytoalbuminologic dissociation }(\mathrm{N}=25)^{n}\end{array}$ & $\begin{array}{r}31(97) \\
31(97) \\
24(75) \\
24(75) \\
20(63) \\
19(59) \\
19(59) \\
25(100)\end{array}$ \\
\hline $\begin{array}{l}\text { Electrophysiologic findings }(\mathrm{N}=5)^{* *} \\
\text { Acute inflammatory demyelinating } \\
\text { polyneuropathy subtype }\end{array}$ & $5(100)$ \\
\hline $\begin{array}{l}\text { Medical interventions } \\
\text { Admitted to hospital } \\
\text { Intravenous immunoglobulin G } \\
\text { Admitted to intensive care unit } \\
\text { Mechanical ventilation }\end{array}$ & $\begin{array}{r}34(100) \\
34(100) \\
21(62) \\
12(35)\end{array}$ \\
\hline $\begin{array}{l}\text { Clinical outcome }(\mathrm{N}=29)^{\dagger} \\
\text { Discharged home } \\
\text { Discharged to rehabilitation center or } \\
\text { skilled nursing facility } \\
\text { Died }\end{array}$ & $\begin{array}{l}15(52) \\
13(45)\end{array}$ \\
\hline
\end{tabular}

* Data for 32 confirmed cases of GBS gathered via patient chart review. Because of chart review criteria, chart review is pending for two suspected cases of GBS with evidence of Zika virus or flavivirus infection.

${ }^{\dagger}$ Does not include five patients still hospitalized as of August 18, 2016.

$\S$ Defined as antecedent illness in the two months preceding onset of neurologic signs, as recorded in the medical record.

" Refers to increased cerebrospinal fluid protein concentration and cerebrospinal fluid total white cell count $<50$ cells/ $\mu$ l. Lumbar punctures were performed and cerebrospinal fluid results were available for 25 patients.

** Electrophysiologic studies available for five patients.

\section{Summary}

What is already known about this topic?

Guillain-Barré syndrome (GBS) is an uncommon autoimmune disorder characterized by varying degrees of weakness, sensory abnormalities, and autonomic dysfunction due to peripheral nerve or nerve root damage. Countries affected by Zika virus have reported increased numbers of cases of GBS. After identification of local transmission of Zika virus in Puerto Rico in December 2015, the Puerto Rico Department of Health implemented the GBS Passive Surveillance System in February 2016.

What is added by this report?

Among 56 patients with suspected GBS who had onset of neurologic symptoms during January 1-July 31, 2016, evidence of Zika or other flavivirus infection was present in 34 $(61 \%)$, including $10(18 \%)$ with confirmed Zika virus infection. The median age of the 34 patients was 55 years, and $59 \%$ were female. Thirty (88\%) patients reported an acute illness before developing neurologic symptoms, with median time to onset of neurologic symptoms of 5 days. One patient died from septic shock after treatment for GBS. Additionally, evidence of Zika virus or flavivirus infection was detected in seven patients with neurologic disorders other than GBS.

What are the implications for public health practice?

Persons with signs or symptoms consistent with GBS should promptly seek medical attention. Health care providers who evaluate patients with neurologic illnesses should consider GBS and report suspected cases to public health authorities. Residents of and travelers to Puerto Rico are advised to follow existing recommendations for prevention of Zika virus infection.

the potential increase in GBS incidence during ongoing Zika virus transmission, health care providers in areas with ongoing local transmission should be familiar with the clinical features of GBS to ensure timely patient diagnosis and treatment. Patients with signs and symptoms consistent with GBS should seek medical attention, regardless of antecedent illness. Health care providers should report suspected cases of GBS and other neurologic conditions to public health authorities.**

\footnotetext{
** http://www.salud.gov.pr/Sobre-tu-Salud/Pages/ProfesionalesdelaSalud. aspx\#gbszika.
} 


\section{Acknowledgments}

Norma Diaz Paris, Juan B. Méndez, Anibal Cruz Sanchez, Jazmín Román, Maria V. Ramos, Zobeida Santiago, Laura Castro, Central and Regional Offices of Epidemiology and Research, Puerto Rico Department of Health; Cesar A. Virgen, MD, University of California San Diego; Elba V. Caraballo, PhD, Koralys Torres Alicea, Damaris Laboy Fernández, Janice Perez, MPH, Vera Soltero, JD, MPH, Division of Vector-Borne Diseases, CDC; Tyler Chavers, Emory University, Atlanta, Georgia; Yvette Lopez Vazquez, San Juan Bautista School of Medicine, Puerto Rico; Brenda Deliz, MD, University of Puerto Rico; University District Hospital, Puerto Rico; Hospital Pediátrico Universitario, Puerto Rico; HIMA-San Pablo, Caguas and Bayamón, Puerto Rico; University of Puerto Rico Hospital Dr. Federico Trilla; Municipal Hospital of San Juan, Puerto Rico; Hospital Auxilio Mutuo, Puerto Rico; Veterans Association Hospital of San Juan, Puerto Rico; Hospital Damas, Puerto Rico; Manatí Medical Center, Puerto Rico; Mayagüez Medical Center, Puerto Rico; Doctor's Center Hospital, Bayamón and Manatí, Puerto Rico; HealthSouth Rehabilitation Center, San Juan, Puerto Rico; Hospital Oriente, Puerto Rico; Hospital Pavia, Arecibo, Santurce, Hato Rey, and Yauco, Puerto Rico; Ryder Memorial Hospital, Puerto Rico.

\footnotetext{
${ }^{1}$ Office of Epidemiology and Research, Puerto Rico Department of Health; ${ }^{2}$ Epidemic Intelligence Service, Division of Scientific Education and Professional Development, CDC; ${ }^{3}$ Division of Vector-Borne Diseases, National Center for Emerging and Zoonotic Infectious Diseases, CDC; ${ }^{4}$ Office for State, Tribal, Local, and Territorial Support, CDC; ${ }^{5}$ Emory University, Atlanta, Georgia; ${ }^{6}$ Department of Neurology and Division of Infectious Diseases, University of Colorado Denver; ${ }^{7}$ Biological and Chemical Emergencies Laboratory, Office of Public Health Preparedness and Response, Puerto Rico Department of Health; ${ }^{8}$ Public Health Laboratory, Puerto Rico Department of Health; ${ }^{9}$ Division of State and Local Readiness, Office of Public Health Preparedness and Response, CDC; ${ }^{10}$ HIMA-San Pablo, Caguas, Puerto Rico; ${ }^{11}$ University of Puerto Rico; ${ }^{12}$ Office of Infectious Disease, National Center for Emerging and Zoonotic Infectious Diseases, CDC.
}

Corresponding author: Emilio Dirlikov, GBS@salud.pr.gov, 787-706-4358.

\section{References}

1. Yuki N, Hartung H-P. Guillain-Barré syndrome. N Engl J Med 2012;366:2294-304. http://dx.doi.org/10.1056/NEJMra1114525

2. Petersen LR, Jamieson DJ, Honein MA. Zika virus. N Engl J Med 2016;375:294-5.

3. Thomas DL, Sharp TM, Torres J, et al. Local transmission of Zika virus-Puerto Rico, November 23, 2015-January 28, 2016. MMWR Morb Mortal Wkly Rep 2016;65:154-8. http://dx.doi.org/10.15585/ mmwr.mm6506e2

4. Dirlikov E, Ryff KR, Torres-Aponte J, et al. Update: ongoing Zika virus transmission-Puerto Rico, November 1, 2015-April 14, 2016. MMWR Morb Mortal Wkly Rep 2016;65:451-5. http://dx.doi. org/10.15585/mmwr.mm6517e2

5. Adams L, Bello-Pagan M, Lozier M, et al. Update: ongoing Zika virus transmission-Puerto Rico, November 1, 2015-July 7, 2016. MMWR Morb Mortal Wkly Rep 2016;65:774-9. http://dx.doi.org/10.15585/ mmwr.mm6530e1

6. Sejvar JJ, Kohl KS, Gidudu J, et al.; Brighton Collaboration GBS Working Group. Guillain-Barré syndrome and Fisher syndrome: case definitions and guidelines for collection, analysis, and presentation of immunization safety data. Vaccine 2011;29:599-612. http://dx.doi. org/10.1016/j.vaccine. 2010.06 .003

7. Cao-Lormeau VM, Blake A, Mons S, et al. Guillain-Barré syndrome outbreak associated with Zika virus infection in French Polynesia: a case-control study. Lancet 2016;387:1531-9. http://dx.doi.org/10.1016/ S0140-6736(16)00562-6

8. Siu R, Bukhari W, Todd A, Gunn W, Huang QS, Timmings P. Acute Zika infection with concurrent onset of Guillain-Barré syndrome. Neurology 2016. Epub July 27, 2016. http://dx.doi.org/10.1212/ WNL.0000000000003038

9. Sejvar JJ, Baughman AL, Wise M, Morgan OW. Population incidence of Guillain-Barré syndrome: a systematic review and meta-analysis. Neuroepidemiology 2011;36:123-33. http://dx.doi.org/10.1159/000324710

10. Araujo AQ, Silva MT, Araujo AP. Zika virus-associated neurological disorders: a review. Brain 2016;139:2122-30. http://dx.doi.org/10.1093/ brain/aww 158 